\title{
THIRTEEN WAYS OF LOOKING AT AMERICA
}

From a car, through a world that's turned to corn, red barns, huge machinery, and a church that says, "Read the Bible, it will scare the hell out of you!"

From the banks of the Iowa River, where a snake comes out of the grass like a belt, testing the air with its buckle-tongue

From the Mark Twain Diner with a Mark Twain Burger and a Mark Twain cup of tea

From another car, Chicago's stickleback in the rearview and the Lake's blue lung swollen with fishing boats

From space, as in the installation by Aaron Koblin in the Museum of Modern Art that shows air traffic over the United States as colored lights, a slow firework spraying in and out during the day, careful and beautiful

From a tour boat in Chicago, where the not-half-decent docent tells us that this building has one hundred and ninety-eight floors, including parking, and was designed by, you guessed it, Merrill, Owings and Skidmore

From the booth of a bar with a sign that says, "I'm Irish, what's your excuse?"

In a nightclub, where you happen upon the Iowa State Drag Queen championships, arms outstretched with dollar bills. This you did not expect

America is standing in a room with Pocahontas, Worzel Gummidge, a bedbug, and at least three Chilean miners. Halloween, in New York City at least, is no longer about darkness and all about just having fun. Something about this disturbs you

I love the way in America the planes fly so low you can really see the fall colors and the cities cut like circuit boards

I love the mechanics and labor of your hand-towel dispensing units. That lever does for me again and again

I love that even in the cold the sky is blue, the sun is out, the air is crisp and clear

$O$, my America, my new found land! Where the poems are as long as the highways, and there is no such thing as a short story 